\title{
Chinese multinational corporations in Brazil: strategies and implications in energy and telecom sectors
}

\author{
Corporações multinacionais chinesas no Brasil: estratégias e \\ implicações nos setores de energia e telecomunicações
}

http://dx.doi.org/10.1590/0034-7329201400108

DANIELLY SILVA RAMOS BECARD* BRUNO VIEIRA DE MACEDO**

Rev. Bras. Polít. Int. 57 (1): 143-161 [2014]

\section{Introduction}

Over the past few years, it has become noticeable that China has provoked an impressive impact in Latin America, especially in investments and trade areas. In Brazil, in particular, China's presence has brought not only cyclical but also structural new challenges, which would lead to questions of increasing concern about China's intentions in various productive sectors in Brazil (Barbosa, Biancalana, and Tepassê 2011; Becard 2013). Moreover, concerns arise from how well Brazil has been adapting itself to the increasing presence of Chinese products and companies in its own market.

In the general framework of China-Brazil relations, it has been found, in particular, that such relations intensified greatly after the first decade of the $21^{\text {st }}$ century. "Trade has been growing almost exponentially, reaching US\$242 billion in 2011. This is a dramatic increase of more than twenty times since 2000, and the growth seems to be accelerating. It jumped 31.5\% from 2010 to 2011." (Shambaugh 2013, 116-117).

Since 2009, thanks to those complementarities between both countries' foreign policies, China has surpassed the United States as Brazil's largest trading partner, with a trade flow of US\$ 75.5 billion in 2012 and of US\$ 83.4 billion in 2013 (or 10\% higher than 2012). According to Frischtak and Soares (2013), Brazil's trade surplus with China, obtained over the past years (US\$ 7 billion only in 2012), helped Brazil to withstand the impact of the international crisis.

* University of Brasília, Brasília, DF, Brazil (daniellyr@yahoo.com).

** University of Brasília, Brasília, DF, Brazil (brunvimac@yahoo.com.br). 
Brazil has responded well to China's voracious appetite for commodities during a super cycle of more than ten years (Murakawa 2014). It has mainly provided an increasing amount of soybeans and iron ore throughout nearly four decades, and oil, more recently. In 2013/2014, the estimated grain harvest was 195 million tons, which was considered a record, particularly revealing the capacity of Brazilian agriculture to react to Chinese demands and contribute to the economic development of the country, either via exports, or via diffusion of technology and integration of several Brazilian regions to markets and global value chains. "The success of Brazilian agricultural is not only the product of our geography, but also of the professional activity, investment in research and increasing technological intensity in production." (Arbache 2014). Despite the achievements of Brazilian agriculture, the limits of commodities for Brazil's development were recognized. In 2012, agriculture contributed with only $5.3 \%$ of GDP and $3.1 \%$ of formal employment (Arbache 2014).

It was noticed, moreover, that the agricultural sector, on the one hand, has responded well to the Chinese presence. On the other hand, the Brazilian manufacturing sector has poorly adapted itself to the presence of an increasingly mighty China, revealing a Brazilian market unprepared to compete on equal terms with Chinese Multinational Corporations (MNCs) (Amorim 2009). There is, indeed, a perception that Brazil has a huge difficulty to include new sectors in its partnership with China. In fact, trade between Brazil and China has been unequal in terms of added value since the beginning of this relationship, almost forty years ago. China has been trading in autos, motorcycles, aircraft and aircraft parts, electronics, and agro-, bio-, nano-, and information technologies (Shambaugh 2013, 118). Brazil, on the other hand, exports largely primary products to China: four products—iron ore, soybean, pulp, and oil—were $81 \%$ of the most exported products to China in 2012 (CEBC 2013).

In this context, Chinese MNCs have found great ways to increase their trade and investment presence in Brazil, generating a highly favorable situation for Chinese businesses. Furthermore, in commercial terms, deviations of market both inside and outside Brazil in favor of China have frequently been observed (Gallaguer and Porzecanski 2010, 52-55). In the productive sector, some analysts believe that there are serious risks of deindustrialization in some specific sectors in Brazil caused by the presence of Chinese manufactured products (made in Brazil or in China). More worryingly, finally, business networks are being established, leading to more Brazilian technological dependence on China (Macedo 2014).

Faced with this situation, it would be necessary to know if Brazil would be seeking to expand its total factor productivity (TFP) (Canuto 2014), moving up in industrial, services, and agricultural value chains, "toward higher value-added activities that require more complex technologies, more skilled human capital and intangible assets such as organizational and project creation capabilities" (Canuto 2014). It would also be important to understand how China would intervene in 
such process. Brazilian agents and researchers would have to understand structures and implications of Chinese international insertion better in order to increase Brazilian chances of adapting itself and seizing opportunities that would be more conformed to its productive interests. Therefore, Brazil could not simply import or imitate existing technologies or capabilities, including those offered by China, anymore, but it would need to create its own (Canuto 2014).

Through the use of Institutional theory of International Relations (Keohane and Nye 1977; Keohane 1984), this study aims at understanding how some key Chinese MNCs have been operating in Brazil over the past ten years, and whether how and why they would be leading to an increase in the asymmetries between the two countries. The specific purposes of this paper are: i) to understand strategies used by Chinese MNCs in Brazil; ii) to examine, through empirical research, the internationalization process of Chinese MNCs in Brazilian energy and telecommunications sectors; and iii) to assess opportunities and risks posed by the increasing presence of Chinese MNCs in Brazil.

This work argues that Brazil-China relations are characterized by asymmetric interdependence due in large part to successful internationalization strategies of Chinese MNCs. In other words, the asymmetrical interdependence that characterizes Brazil-China relations is due to successful Chinese going global strategies, adopted by its MNCs.

\section{Background and propositions}

In this work, institutions are presented as "formal rules, compliance procedures and standard operating practices that structure relationships between individuals in various units of the polity and the economy" (Hall 1986, 20 apud Savigny and Marsden 2011, 112). Multinational corporations (MNCs), as a specific kind of institution, are defined here as "a firm that owns and manages economic units in two or more countries. Most frequently, it entails foreign direct investment (FDI) by a corporation and the ownership of economic units (services, extractive industries, or manufacturing plants) in several countries" (Gilpin 1987, 231). In general terms, the main objective of an MNC is to secure the least costly production of goods, goal that could be achieved by acquiring the most efficient locations for production facilities or obtaining taxation concessions from host countries (Gilpin 1987, 232).

According to some Institutionalists, institutions are not always efficient and cooperation does not always generate more profits. For Keohane and Nye, relations of cooperation and interdependence should not be understood only through the prism of effects mutually benefic or equally balanced between the parties. The interdependent relationships often present particular distributive characteristics, influenced by power relations that allocate the gains resulted from exchange unequally. This unequal distribution of earnings makes an actor more sensitive or vulnerable than another. The worst result of cooperation between two actors 
or institutions would be one in which one actor has no viable alternatives in the foreseeable future to change a frame that is not favorable to it, having to bear the costs imposed by changes in the relations with other actors (Keohane and Nye 1977, 10-13).

According to Dicken $(2011,61)$, MNCs have basic features that have promoted the emergence of new forms of production, income generation and power relations: the ability to coordinate and control multiple processes and transactions in the context of global production networks, the potential to extract advantages from differences in the geographical distribution of production factors, and the potential geographical flexibility, allowing them to transfer resources and operations across locations and countries. Since the 1990s, in particular, MNCs have acquired new features, accompanying the changes in the modes of production. Among them, we highlight the fact that MNCs started being considered as business networks that operate in the midst of other business networks (networks within networks) (Dicken 2011, 121).

According to Pind Deng (2009), Chinese MNCs tend to acquire strategic assets-those resources and capabilities that are valued by the firm for their potential to contribute to competitive advantage-in international expansion for some particular reasons: i) to adapt to the prevailing corporate values and norms; ii) to conform to the home country institutional environment; and iii) to respond to government's development plan in order to compete successfully in the global landscape.

First, it is affirmed that Chinese MNCs conform themselves to the rules and beliefs of the system in order to acquire legitimacy. Under this argument, Chinese firms are especially motivated to seek legitimacy or approval for their actions from those constituents on which the firms depend for critical resources (Oliver 1997 apud Deng 2009, 75). Second, Chinese MNCs are constrained by an institutional environment of continuous economic liberalization and gradual institutional transition and substantial roles played by the government: "As part of economic reforms, the Chinese government has maintained political control and also maintained its ability to reward and discipline firms for their adherence to its directives" (Deng 2009, 75). In addition, corporate strategic decisions in China are, to a large extent, governed by a mix of political and economic motives (Deng 2009, 76). In this sense, the Chinese government has been creating different supports to stimulate strong Chinese firms to invest abroad for the purpose of becoming globally competitive. Especially since 2001, the "going global" strategy would seek Chinese firms to invest overseas as part of China's overall strategy of joining global competition and adjusting itself to the trend of economic globalization. Additionally, there are several economic factors at play, which can be categorized as less concerned with the environment of the home country and more with the host countries. As an example, the pull from host countries can be explained by the fact that Chinese investments look attractive to foreign companies trying to finance their projects but unable to access bank financing (Tan 2013, 757). 
China's emergence as a global direct investor entails a number of consequences, which are yet to be understood. The next section seeks to shed light on the drivers and division-making process of China's investments in Brazil from the perspective of energy and telecommunication sectors.

\section{The Chinese investments in the Brazilian energy sector}

China has become a new investor and credit supplier to the Brazilian market since the second half of the 2000s, giving a new profile of these bilateral relations, and giving some relief to discontentment in the commercial area. In 2012, 45\% of Chinese investments flows went to six countries: United States (US\$ 167 billion or $12 \%$ of total), China (US\$ 121 billion), Hong Kong (US\$ 74 billion), Brazil (US\$ 65 billion), British Virgin Islands (US\$ 65 billion), United Kingdom (US\$ 62 billion) and Australia (US\$ 57 billion).

In Brazil, Chinese companies at first (until 2010) invested in industries related to natural resources and energy. As of 2011, Chinese companies have also invested in the Brazilian manufacturing sector, in particular through the creation of new businesses (Greenfield), but also through the acquisition of existing companies (including some of European origin) (Frischtak and Soares 2013). The number of Chinese investment projects in Brazil has not ceased growing. As an example, the China Brazil Economic Council (CEBC) recently identified 60 investment projects announced by 44 Chinese firms and estimated a total investment of US\$ 68.5 billion (CEBC 2013, 8). The total value of confirmed investment amounted to US\$24.4 billion over the period 2007-2012. The next sections will study the cases of Chinese companies operating in energy and telecom sectors.

According to the International Energy Agency (IEA 2013), Brazil-China relations in the energy sector have intensified over the past decade due to the increased innovation capacity and generation of investment flows between the two countries. From 2005 to 2012, the Brazilian energy sector accounted for US\$ 18.3 billion from Chinese investments. For that Agency, elements such as the Brazilian abundance of energy resources, China's great potential to finance projects, and the increased Brazilian and Chinese ability to expand their technological capabilities explain the emergence of new business opportunities (IEA 2013).

The IEA also believes in the potential of Sino-Brazilian cooperation in the petrochemical industry due to Brazilian oil reserves and China's ability to fund its exploration and development. Meanwhile, Petrobras has developed, in recent years, oil exploration technology in deep waters, which China does not have. More recently, the Chinese State Grid Company revealed its interest in settling permanently in Brazil, increasing its investments in the electricity market.

The victory of IE Belo Monte Consortium, formed by the Chinese MNCs State Grid Brazil Holding S.A. (51\%), along with Brazilian companies Furnas Central Electric S.A. (24.5\%) and the North Central Electric S.A. Brazil (Eletronorte) (24.5\%), consolidates a new investment cycle in the Brazilian electric 
sector, marked by the presence of Chinese leading companies, instead of MNCs from Western developed countries (Facchini et al. 2014).

The winner consortium offered a proposal of annual remuneration of $\mathrm{R} \$ 434,647,038.00$ (approximately US\$185,667,000.00) or 38\% lower than the ceiling set by the Brazilian government (Alvarenga 2014). This bid was considered unbeatable and demonstrated Beijing's strong interest in settling permanently in Brazil. The two other bidders offered far more modest proposals: the Spanish group Abengoa - a major investor in transmission lines in Brazil since 1994-offered a discount of $11.49 \%$. The consortium formed by Taesa and Alupar offered a discount of $4.93 \%$.

The IE Belo Monte group will be responsible for the construction of the transmission line that will drain energy produced by the Belo Monte dam in Pará to the Southeast Region of Brazil. The line will have an extension of 2,100 km, with an estimated cost of $\mathrm{R} \$ 5.1$ billion. The line should be concluded in January, 2019. According to the president of Eletrobras, Jose da Costa Carvalho Neto, the company State Grid has committed to fund approximately $10 \%$ of the project. BNDES loans should cover between $50 \%$ and $55 \%$ of costs. For some analysts, Chinese enterprises' high capacity to finance businesses in Latin America is due to the fact that they have access to low-cost capital, which allows Chinese stateowned enterprises (SOEs) to offer lower rates of return for infrastructure projects, which require heavy investments (Facchini et al. 2014). The president of Eletrobras also said that the aggressive proposal made by the consortium was possible due to prior arrangements with contractors and suppliers, which have enabled the consortium to expect to work for a price below US $\$ 5.1$ billion, suggested by the Brazilian Energy Agency-Agência Nacional de Energia Elétrica (ANEEL) (Alvarenga 2014).

The Chinese company State Grid has been in Brazil since 2010, when it acquired seven energy transmission companies, which belonged to the Spanish group Actividades de Construcción y Serviços (ACS), and another company from Plena Transmissora group, for the sum of US\$ 989 million. State Grid has since then become the owner of 12 transmission concessions in the country, besides being partner with domestic companies in three more concessions, two with Copel and one with Furnas. In 2012, State Grid inaugurated its headquarters in Rio de Janeiro, with an investment of US\$ 85.4 million and announced a new investment of US $\$ 5$ million by 2015 in Brazil. State Grid had 300 employees in 2014 (State Grid Brazil Holding 2014). In the near future, State Grid, which supplies power to an amount equivalent to $88 \%$ of China's territory, for a population of over 1 billion people, plans to expand its business in Brazil. In the area of electric energy, the company's strategy is to establish a platform for consistent investment in power transmission, but also in power generation and distribution. State Grid also wants to evaluate the possibility of future investments in wind and solar energy (State Grid Brazil Holding 2014). 
The fact that the three state-owned Chinese oil companies (CNOOC, CNPC and Sinopec-through joint ventures Repsol/Sinopec and Petrogal) have contributed to the auction promoted by the Brazilian National Agency of Petroleum, Natural Gas and Biofuels (ANP), for the granting of oil exploration in the Libra oil field (the pre-salt region), reflects the growing interest of China's government in this source of Brazilian energy. This interest relates not only to the demands from the Chinese economic growth itself-that must re-take the momentum with increased domestic consumption in the composition of the country's Gross National Product (GNP) and with the reheat of European and North American markets-but also to the need China has to diversify its suppliers in order to reduce energy dependence on the Middle East, in particular.

In 2012, according to the Brazilian National Petroleum Agency (ANP 2013), China's oil reserves stood at 17.3 billion barrels, the $14^{\text {th }}$ largest in the world. However, the growth rate of these reserves has been slow over the past decade, remaining at an annual average rate of $1.1 \%$. Consumption, in turn, grew in the last decade, at an average rate of $7 \%$ per year, reaching, in 2012, 10.2 million barrels/ day (mbd) (ANP 2013).

In China, production rose on average $2.2 \%$ per year to meet the domestic consumption in ten years, and registered, in 2012, $4.1 \mathrm{mbd}$. Although this result has positioned China as the world's fourth largest producer, production supplied only $40 \%$ of the domestic demand; the other $60 \%$ were obtained through imports originated, mostly, from the Middle East (Figure 1). In 2012, China imported 45.5 million barrels from Brazil, which could cover only $2 \%$ of Chinese importsthe same percentage was registered in 2013 (ANP 2013; EIA 2014).

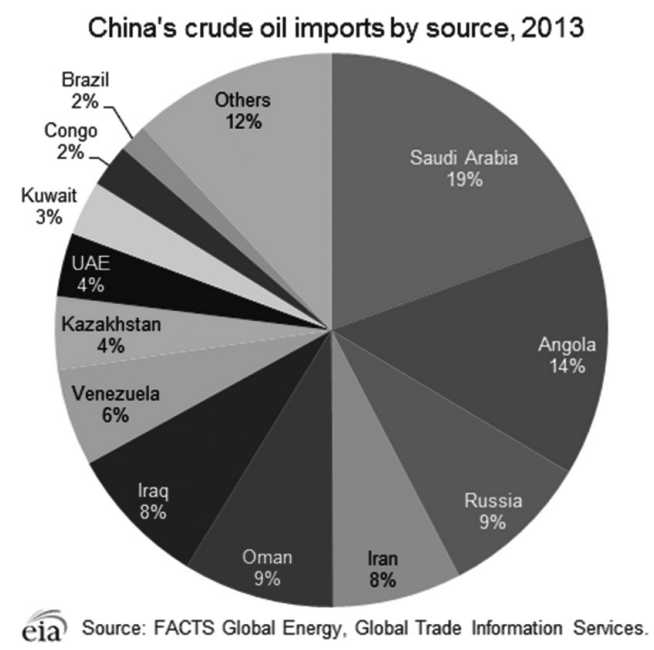

Figure 1. Chinese oil imports (by country of origin).

Source: EIA (2014). 
Since 1994, China has become a net oil importer, and in 2013 it was the second largest country oil importer in the world $(6.2 \mathrm{mbd})$, only behind the United States $(6.6 \mathrm{mbd})$. This demand for oil in China occurred despite the fact that the product accounted for only $18 \%$ of the country's energy matrix (Figure 2) (EIA 2014).

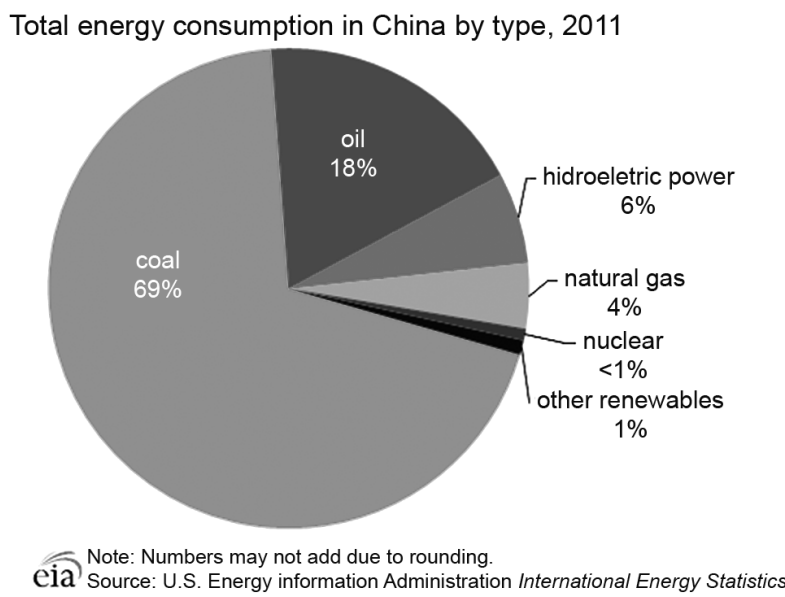

Figure 2. Chinese energy matrix (2011).

Source: EIA (2014).

In the near future, the oil supply from South American sources to the Chinese market may be favored by three major infrastructure projects underway in Central America and the Caribbean: the expansion of the Panama Canal, the construction of the Nicaragua Canal and the completion of the Port of Mariel in Cuba. Actually, the locks of the Panama Canal cannot receive large oil vessels, which forces navigation through other routes, which increases both travel time to China and freight costs — climate conditions in the Strait of Magellan (crossing Atlantic/Pacific) make navigability difficult; in the Strait of Malacca (crossing Indian/Pacific), there are recurrent actions of maritime piracy.

With the prospects for increased Chinese oil demand, as well as with the improvement of transport infrastructure, the tendency is to observe more Brazilian oil exports to China, especially after the victory of the consortium formed by Petrobras ( $40 \%$ of participation), Shell $(20 \%)$, Total $(20 \%)$, and by Chinese state-owned companies CNPC (10\%) and CNOOC (10\%), authorizing the exploitation of oil resources in the Libra field. The estimated volume of oil for this field is between 8 billion and 12 billion barrels, representing between $46 \%$ and $70 \%$ of China's current reserves.

This partnership between CNOOC and CNPC in the same consortium for oil exploration was the first of its kind in the world. Until then, there was 
an occurrence only of a partnership between CNOOC-Sinopec and CNPCSinopec. Partnerships with Sinopec follow particular characteristics, according to the origins of these three state enterprises, which were created in the 1980s, with different goals: CNOOC was in charge of the exploitation of offshore oil, CNPC was linked to the onshore exploration, and Sinopec was responsible for refining and petrochemicals. Over time, the three companies started investing in several activities, different from the original ones, although they have maintained much of their operations concentrated in those areas where they already had expertise (The Heritage Foundation 2014; Jiang and Sinton 2011).

Between 2005 and 2013, among the three Chinese state-owned companies, Sinopec was the main responsible for FDI around the world, which totaled US\$ 68.2 billion in the period. CNPC was the second company with the largest volume of FDI (US\$ 62 billion). CNOOC invested US\$ 37.4 billion during the same period (The Heritage Foundation 2014).

The analysis of the temporal distribution of these FDIs allows concluding that the Chinese government promoted in recent times waves of energy investments (Figure 3), switching companies responsible for investments. These waves (which totaled nearly US\$ 16 billion each) show that in 2013, when the auction of the Libra oil field took place, Chinese SOEs (especially CNOOC) were significantly undercapitalized, hence explaining why they participated as minority members in the consortium that won the auction.

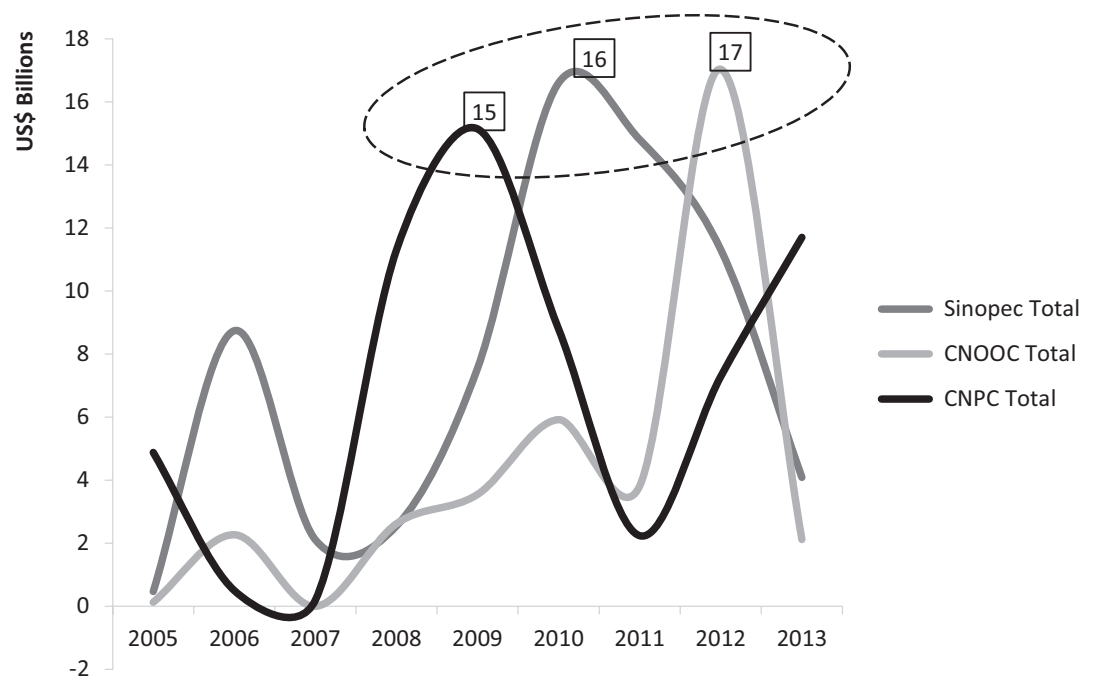

Figure 3. Total investments of Chinese state-owned enterprises in the petroleum sector in the world.

Note: The Heritage Foundation accounts only investments exceeding US\$ 100 million.

Source: elaborated with data from The Heritage Foundation (2014). 
The analysis of the geographical distribution of the FDI undertaken by oil Chinese SOEs provides additional information about the place of Brazilian oil investments in these companies' agenda. Between 2005 and 2013, most of Chinese investments were concentrated in North America (especially for the acquisition by CNOOC of the Canadian oil company Nexen for US\$15 billion in 2012). Secondly, Chinese investments were concentrated in Africa, the Middle East and, only then, these investments were directed to South America (The Heritage Foundation 2014; Lee 2012).

From the total IED applied by the Chinese SOEs in South American countries, $54 \%$ was allocated in Brazil-91\% of which was invested by Sinopec. The presence of CNOOC and CNPC in Brazil is negligible. Until the participation in the Pre-Salt auction, CNOOC had no investments in the country, and CNPC operated only via joint venture formed in 2011 by one of its subsidiaries-Baoji Oilfield Machinery Co. (Bomco)—and Asperbras companies and Brazil-China Oil. The joint venture called Bomcobras Business and Equipment for Oil and Gas was founded with the goal of producing machinery for the Brazilian oil exploration industry (The Heritage Foundation 2014; Moura 2011).

In view of the foregoing data, it can be said that the participation of oil companies CNOOC and CNPC in the consortium that won the auction of the Libra oil field was a business opportunity. South American in general and the Brazilian market in particular were not yet among those companies' priorities (especially CNOOC). At that occasion, those companies had just undergone heavy investment in previous years, using great sums of money, decapitalizing themselves. The opportunity, however, to participate in the exploitation of deposits which may represent up to $70 \%$ of current Chinese reserves, and the prospects for growth in global oil demand in China, as well as the reduction in transportation costs of the South American oil into the Asian country, led Chinese companies to seek participation in the winning consortium, even though on a minority basis.

\section{The Chinese presence in the Brazilian Telecom sector}

In almost thirty years of existence, the two largest Chinese companies in the telecommunications industry, Huawei Technologies and Zhongxing Telecommunication Equipment (ZTE), transformed the international market for telecom equipment. Currently, these companies compete with other MNCs for the leadership in different segments of the global production chain and stand out among the leading companies that submit patent applications at the World Intellectual Property Organization (WIPO) (Ahrens 2013, 13-14; Beiguang 2008; WIPO 2009; 2012; 2013).

However, when these companies emerged in the second half of the 1980s, the Telecom sector was dominated worldwide by North American, European, and Japanese MNCs. In the Chinese territory, the situation was not different; French 
companies such as Alcatel, Germany's Siemens, and Japan's NEC controlled the market in that country from joint ventures established with local companies (Harwit 2008). Huawei and ZTE succeeded in gaining market and circumventing the dominance of foreign MNCs due to three main factors. First, the decisive support of the Chinese government facilitated the transfer of technology and financial resources to these companies and offered political support to conquer markets not only in its own country but also in other parts of the world (Harwit 2008; Malerba and Nelson 2012). Secondly, one must consider the indirect support provided by global leading companies in specific technological segments, with which Huawei and ZTE have formed strategic alliances. Such alliances were important for the training of Chinese enterprises in terms of research and development $(\mathrm{R} \& \mathrm{D})$ of high-tech products. It was from these alliances that Huawei and ZTE have gained expertise in manufacturing equipment operating under different technological standards (Ying 2013).

Finally, Huawei and ZTE had a successful marketing strategy based on offering products similar to foreign ones, but at a considerably lower cost, seeking to gain ground, first, with less-demanding and less-power-consumption markets (as in rural areas), to then compete in major consumer centers markets. Globally, this strategy was initially based on the search of markets in developing countrieswith the goal of acquiring production scale and international experience-and only then in the entrance in developed markets. It was in the context of this strategy that Huawei and ZTE companies settled in Brazil in 1999 and 2002, respectively (Ahrens 2013, 24; Beiguang 2008, 23; Larçon and Barré 2009, 146; Jin 2009, 25; Huawei 2013; 2008, 14; ZTE 2012).

The arrival of these companies in Brazil occurred nearly a decade after the Brazilian economy opening process and shortly after the privatization process of the national telecommunications system (1997-1998). This process generated a major structural impact on the telecom industrial complex that existed in the country and deepened Brazil's external vulnerability in this sector. With the dismantle of the state system headed by Telebras since the 1970s, a fragile situation took place, very similar to the weakness experienced by the country prior to nationalization, namely: the need to import foreign equipment to meet demands for improvements and expansion of Brazilian telecommunications networks (Szapiro 2005; 2012; Tatsch 2003, 51-54; Neves 2002, 302).

The activities performed by those two Chinese MNCs in Brazil, in general, presented certain complementarities, due to informal division of labor that avoided duplication of efforts and reduced competition between their products. While Huawei turned to the segment of infrastructure equipment-being responsible, as well, for the implementation of parts of the $3 \mathrm{G}$ and $4 \mathrm{G}$ networks of almost all operators in the country-, ZTE focused on the cell phones market. The cases involving the operators Vivo and Tim are emblematic: while Huawei signed 
contracts to install 3G networks for both companies, ZTE won contracts to supply terminals (phones and modems) for these same 3G operators.

By doing so, it can be said that Huawei and ZTE not only contributed to the rapid expansion of telecommunications networks in the country, but also for mutual expansion of their own business. This is because the installation of equipment capable of extending phone signal coverage at a particular location not previously met automatically expands the potential consumer market for mobile phones in that locality. In another movement, a larger volume of mobile phones in population hands tends to generate demand for improvement and expansion of signal coverage, which is attended by investments in network infrastructure and acquisition of new equipment.

Thus, we must recognize the importance of Telecom products provided by these two Chinese MNCs to reach the goal of $100 \%$ of Brazilian municipalities served by mobile phone in 2011 (Telebrasil 2013, 108). The contribution of Huawei and ZTE to the expansion of infrastructure and access to telecommunications in the country, moreover, motivated the visit by the President of Brazil, Dilma Rousseff, to the headquarters of these companies, in China, during an official visit to the Asian country in April 2011 (Teletime 2011; Estado de S. Paulo 2011). The visit to these two companies also had another goal: to attract investment to Brazil in more technologically advanced sectors. On that occasion, Huawei announced an investment of US\$350 million to build a center for R\&D in Campinas, SP; ZTE announced an investment of US $\$ 200$ million to create an industrial park in the city of Hortolândia, SP (Teletime 2011; Estado de S. Paulo 2011). However, by January 2014, the beginning of these works had not been disclosed.

It should be noted that the contribution of Huawei and ZTE for the expansion of mobile telephony in Brazil became a reality, largely through the import of products and equipment manufactured in Chinese territory. Such imports converted stimuli generated by investments in the Telecom sector in Brazil into benefits for the Chinese industry demands. This conversion sterilized an important part of the effects these investments could have had on the development of the Brazilian manufacturing complex.

This argument is better understood when analyzing the Brazilian Telecom sector in 2008, when national operators began installing their $3 \mathrm{G}$ networks. That year, Huawei was responsible for deploying $3 \mathrm{G}$ networks for Vivo, Tim, Claro, Oi, CTBC and Sercomtel (Teleco 2013) operators. Without owning a factory in Brazil, the implementation of these projects occurred largely by the import of equipment, coming mainly from Huawei factories in China.

Thus, in 2008, the company recorded imports of US\$ 258 million (Figure 4), 64 times higher than those imported by the same company in the previous year. That placed Huawei as the largest importer of goods to Brazil among the leading providers of equipment of Telecom infrastructure in the domestic market (MDIC 2012). 


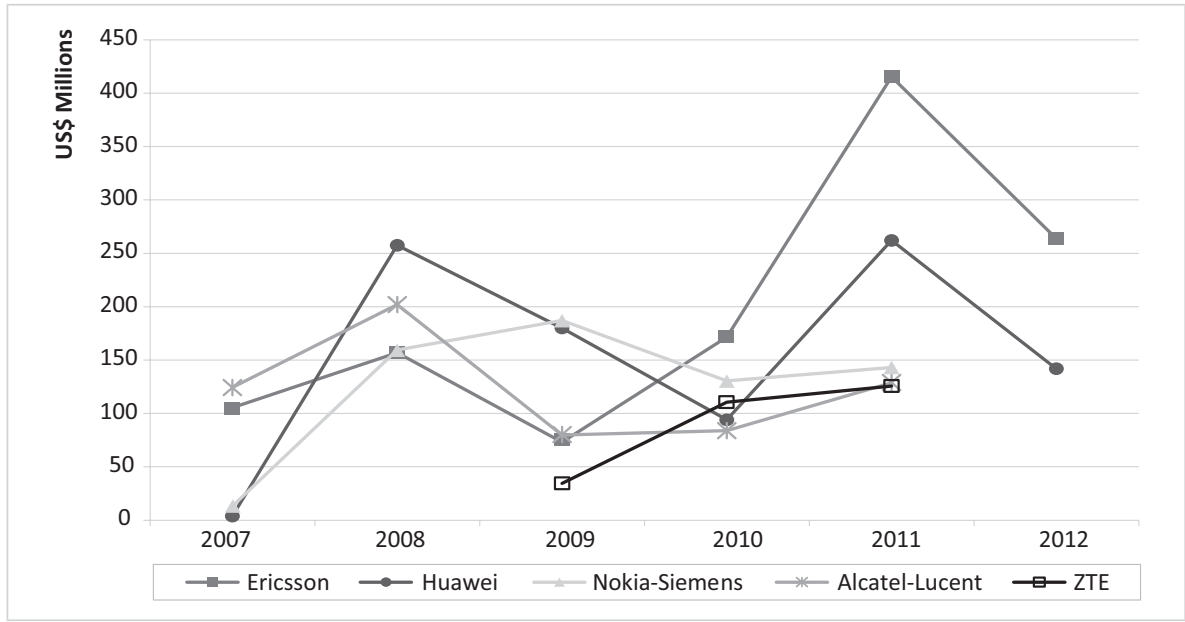

Figure 4. Value of imports of the leading telecom equipment manufacturers in Brazil (2007-2012).

Source: elaborated with data from MDIC (2013).

It should be recalled in this context that, in 2008 , one of the worst global economic crisis in recent history broke out, and that imports of products from China Telecom had significantly negative impacts on all of the Brazil-China trade balance. That year, according to the Ministry of Development, Industry and Foreign Trade (MDIC), Brazil recorded the worst deficit (US\$ 3.6 billion) in total trade with China throughout the period 2000-2013. From this deficit, US\$ 1.1 billion was generated in the Telecom sector-a negative result that was overcome only in 2011 with the opening of $4 \mathrm{G}$ networks installation (Figure 5).

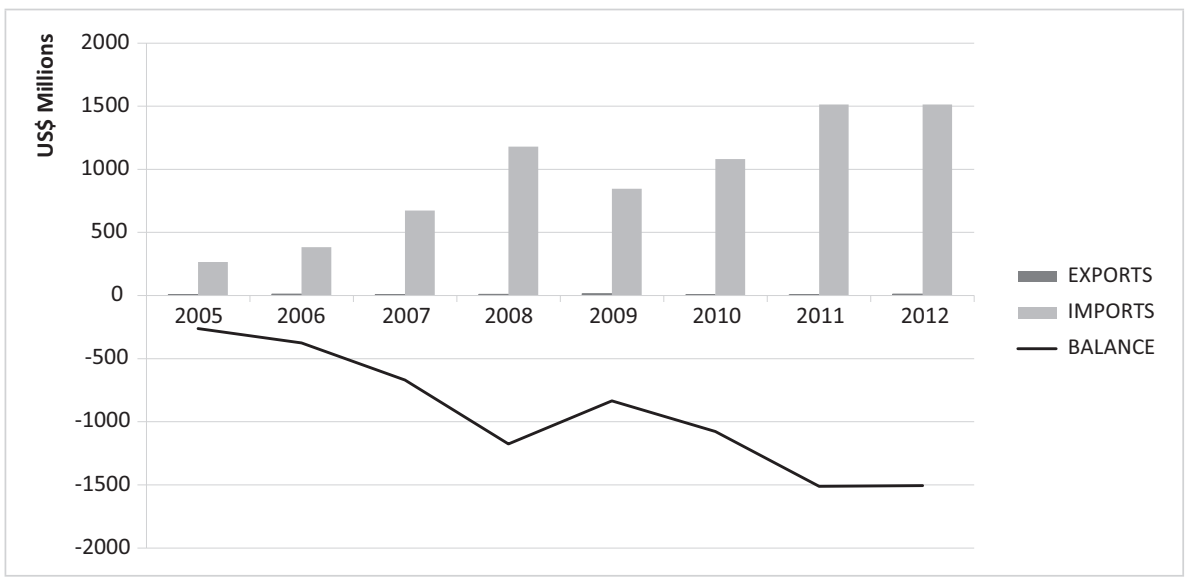

Figure 5. Brazil-China trade balance of telecommunication equipment.

Source: elaborated with data from <http://www.teleco.com.br/telbalcom.asp $>$. 
In 2010, it was ZTE's turn to register higher sums on imports (US\$ 111 millions) and place itself as the third supplier of telecom equipment to the Brazilian market. This increase in imports from ZTE sought to fill gaps in supply for mobile operators Vivo and Tim; these gaps were generated by the closure of the Canadian company Celestica's operations in Brazil, which manufactured cell phones and other equipment for ZTE.

In 2011, a new record was registered in Huawei imports (US\$ 262 million), this time related to investments for the deployment of $4 \mathrm{G}$ networks in the country. That year, the sum imported by Huawei was only lower-among the companies also responsible for deploying $4 \mathrm{G}$ networks - than the sum imported by Ericsson (US\$ 415 million), responsible for installing a larger amount of $4 \mathrm{G}$ networks than Huawei.

The growth of Huawei's and ZTE's businesses in Brazil, while allowing the expansion of telecommunications in the country, has generated significant impacts on the Telecom trade balance between Brazil and China. These impacts were related to investments in the sector to modernize and expand networks. This, in fact, is not a new phenomenon in the history of the Brazilian Telecom sector, but it was deepened with the performance of Chinese enterprises in the domestic market. By transforming stimuli generated by needs for investment into demand for imports, these companies, as well as others who were acting in the domestic market, exerted deleterious effects on the development of the Telecom productive chain on Brazilian soil. It is urgent, therefore, to promote the migration of part of the production chain of those and other companies established in Brazil. By not doing so, more business networks could be established without the participation of Brazilian companies, leading to more Brazilian technological dependence on China.

\section{Conclusions}

Since the beginning of the $21^{\text {st }}$ century, Chinese MNCs have been transforming the commercial and investment scenarios in Brazilian energy and telecom sectors in many visible ways. Among the most important domestic incentives for internationalization, we found the domestic institutional environment of continued economic liberalization and institutional transition. The role of the government was also of great importance to finance international projects, to generate political incentives in business processes, and to award and discipline enterprises for their adherence to its policies. In the host country, Chinese investments looked attractive to foreign firms wishing to fund their projects at low prices.

In the energy sector, elements such as the Brazilian abundance of energy resources and China's capacity to finance projects and Brazilian and Chinese ability to expand their technological capabilities explained the emergence of new business opportunities. The Chinese participation in the IE Belo Monte Consortium represented a new cycle in the Brazilian electric sector, characterized 
by the presence of Asian, and not Western developed countries. The high capacity of Chinese and Brazilian firms of that Consortium to finance the business was explained by the fact that it had access to low-cost capital, as well as to prior arrangements with contractors and suppliers, which enabled the Consortium to work with lower prices.

The participation of State-owned Chinese oil companies CNOOC and $\mathrm{CNPC}$ in the Consortium that won the auction for the granting of oil exploration in the Libra oil field, on the other hand, was more the result of a business opportunity. At that moment, the Brazilian market was not yet among those companies' priorities. The opportunity, however, to participate in the exploitation of deposits that represented more than $70 \%$ of current Chinese reserves and diminish the dependence towards other oil sources led Chinese companies to seek participation in the Consortium, even though on a minority basis.

In the Telecom sector, Huawei and ZTE succeeded in gaining market and circumventing the dominance of foreign MNCs due to decisive support of the Chinese government which facilitated the transfer of technology and financial resources to these companies and offered political support to conquer markets in Brazil and other parts of the world. The indirect support provided by global leading companies in specific technological segments, with which Huawei and ZTE have formed strategic alliances, was also decisive for their success in Brazil. Finally, Huawei and ZTE have chosen a very successful marketing strategy, based on offering products similar to foreign ones, but at a considerably lower cost, seeking to gain ground, first, with less-demanding and less-power-consumption markets (as in rural areas), to then compete in major consumer centers markets. Globally, this strategy was initially based on the search for markets in developing countries, like Brazil — with the goal of acquiring production scale and international experience-and only then on the entrance in developed markets.

Although Telecom products provided by Huwaei and ZTE were very important to reach the goal of $100 \%$ of Brazilian municipalities served by mobile phone in 2011, such imports converted stimuli generated by investments in the Telecom sector in Brazil into benefits for the Chinese industry demands. This conversion sterilized an important part of the effects these investments could have had on the development of the Brazilian manufacturing complex. Without owning a factory in Brazil, the implementation of these projects occurred largely by the import of equipment coming mainly from Huawei factories in China, a huge impact in commercial balance between the two countries. In the near future, the continuum absence of Brazilian companies in more telecom business networks could lead not only to more trade imbalances, but also to huge Brazilian technological dependence, especially on China.

From the Brazilian point of view, on the one hand, Chinese MNCs' great capacity to finance projects at low prices, to offer technological capacity, and to use political and economical support from the Chinese Government to prospect 
new business plans were fundamental to some Brazilian projects in the energy and telecom sectors. On the other hand, in the telecom sector, the growth of Huawei's and ZTE's businesses in Brazil, even though contributing to the Brazilian goal of $100 \%$ of Brazilian municipalities served by mobile phone, exerted deleterious effects on the development of the Telecom productive chain on Brazilian soil.

\section{Bibliographic references}

AHRENS, Nathaniel (2013). China's competitiveness: Myth, reality, and lessons for the United States and Japan. Case Study: Huawei. Report of the CSIS Hills Program in Governance. Washington: CSIS, February 2013. [http://csis.org/files/publication/130215_competitiveness_Huawei_ casestudy_Web.pdf]Disponibilidade: 13 out. 2013.

ALVARENGA, Darlan (2014). Consórcio de chineses e Eletrobras vence leilão de linha de Belo Monte. Globo 1 Economia, 07 fev. 2014. [http://g1.globo.com/economia/noticia/2014/02/ consorcio-de-chineses-e-eletrobras-vence-leilao-de-linha-de-belo-monte.html]. Disponibilidade: 25 fev. 2014.

AMORIM, Renato (2009). China: Três Décadas de Crescimento Econômico e Projeção Internacional. Texto apresentado durante o $6^{\circ}$. Forum de Economia da Fundação Getúlio Vargas. São Paulo, 2009. [http://bibliotecadigital.fgv.br/dspace/handle/10438/8351]. Disponibilidade: 3 jan. 2013.

ANP, Agência Nacional do Petróleo, Gás Natural e Biocombustíveis (2013). Anuário Estatístico Brasileiro do Petróleo, Gás Natural e Biocombustiveis 2013. [http://www.anp.gov.br/?pg=66833] Disponibilidade:: 11 fev. 2014.

ARBACHE, Jorge (2014). Parceria Vencedora. Valor Econômico, 27/02/2014. [http://www. valor.com.br/colunistas/Jorge\%20Arbache\%20] Disponibilidade: 27 fev. 2014.

BARBOSA, A.; BIANCALANA, M. N.; TEPASSÊ, A. C. (2011). A Ascensão Chinesa e os Impactos sobre a América Latina e a África: objetivos comuns, estratégias diferenciadas. XI Congresso Luso Afro Brasileiro de Ciências Sociais: Diversidades e(Des)igualdades. Salvador, UFBA, 07 a 10 de agosto de 2011.

BECARD, Danielly R. (2013). China Diplomacy and Trade in Latin America. Estudos Internacionais. Vol 1, n. 2, 2013.

BEIGUANG, Zhu (2008). Internationalization of Chinese MNEs and Dunning's Eclectic (OLI) Paradigm: A Case study of Huawei Technologies Corporation's Internationalization Strategy. Tese de Mestrado em Economia pela Universidade de Lund (Suécia). Lund, June 2008. [http:// lup.lub.lu.se/luur/download?func=downloadFile\&recordOId=1338205\&fileOId=1646725] Disponibilidade: 13 out. 2013.

CANUTO, O. (2014). O que vem freando o Brasil? Valor Econômico, 25/02/2014.

CEBC, Conselho Econômico Brasil - China (2013). Chinese investments in Brazil from 2007-2012: A review of recent trends, 2013. [http://cebc.com.br/sites/default/files/pesquisa_ investimentos_chineses_2007-2012_-_ingles_1.pdf] Disponibilidade: 01 fev. 2014.

DENG, Ping (2009). Why do Chinese firms tend to acquire strategic assets in international expansion? Journal of World Business, 44, p. 74-84, 2009. [http://www.sciencedirect.com/science/ article/pii/S1090951608000175] Disponibilidade: 06 fev. 2014. 
EIA (2014). U.S. Energy Information Administration. Country Reports: China Febuary 4, 2014. [http://www.eia.gov/countries/cab.cfm?fips=CH] Disponibilidade: 11 fev. 2014.

ELIAS, Jô (2004). Brasil é a bola da vez para ZTE. Torque, 09/05/2004. [http://www.torque. com.br/index.php?modulo=entrevistas\&secao=entrev] Disponibilidade: 22 dez. 2013.

ESTADO DE S. PAULO (2011). Dilma visita ZTE, que investirá US\$ 200 mi no Pais. 15 de abril de 2011. [http://economia.estadao.com.br/noticias/neg\%C3\%B3cios, dilma-visita-zteque-investira-us-200-mi-no-pais,63103,0.htm] Disponibilidade: $22 \mathrm{dez} .2013$.

FACCHINI, Claudia; ALONSO, Olivia; PEDROSO, Rodrigo; POLITO, Rodrigo (2014). Vitória de Belo Monte marca avanço da China no Brasil. Defesanet. 10 fev. 2014. [http://www. defesanet.com.br/brasilchina/noticia/14152/Vitoria-de-linhao-de-Belo-Monte-marca-avancoda-China-no-Brasil/] Disponibilidade: 25 fev. 2014.

GALLAGUER, Kevin P.; PORZECANSKI, Roberto (2012). The Dragon in the room: China $\&$ The Future of Latin American Industrialization. Stanford: Stanford University Press.

HARWIT, Eric (2008). China's Telecommunications Revolution. Oxford: Oxford Univ. Press, 2008.

HUAWEI (2008). Brazil Telecom - Market Presentation. 2008. [http://www.cebc.org.br/sites/ default/files/apresentacao_alex.pdf] Disponibilidade: 13 out. 2013.

HUAWEI (2013). Latin America Fact Sheet. [http://www.huawei.com/in/about-huawei/ newsroom/resources/latin_america/index.htm] Disponibilidade: 13 out. 2013.

INTERNATIONAL ENERGY AGENCY (2013). Energy Investments and Technology Transfer Across Emerging Countries: the case of Brazil and China. OCDE / IEA, 2013. [http://www. iea.org/publications/freepublications/publication/PCS_ChinaBrazil_FINAL_WEB.pdf] Disponibilidade: 15 dez. 2013.

JIANG, Julie; SINTON, Jonathan (2011). Overseas investments by Chinese national oil companies: Assessing the drivers and impacts. Information paper - International Energy Agency (IEA). February, 2011. [http://www.iea.org/publications/freepublications/publication/overseas_china. pdf] Disponibilidade: 11 fev. 2014.

JIN, Zhanming (2009). Corporate Strategies of Chinese Multinationals. IN: LARÇON, Jean-Paul. Chinese Multinationals. Cingapura: World Scientific Publishing.

LARÇON, Jean-Paul; BARRÉ, Geneviève (2009). Technology-Based Competition and Chinese Multinationals. IN: LARÇON, Jean-Paul. Chinese Multinationals. Cingapura: World Scientific Publishing.

LEE, Chyen (2012). Petrolifera chinesa CNOOC oferece US\$15 bi por Nexen. G1 Economia, 23/07/2012. [http://g1.globo.com/economia/noticia/2012/07/petrolifera-chinesa-cnoocoferece-us15-bi-por-nexen.html] Disponibilidade: 11 fev. 2014.

LEO, Sérgio (2006). ZTE produzirá celular em parceria com Evadin. Valor Econômico, 01/09/2006. [http://www2.senado.leg.br/bdsf/bitstream/handle/id/468881/noticia. htm?sequence=1] Disponibilidade: 22 dez. 2013.

MACEDO, Bruno V. (2014). O Great Game Tecnológico das Multinacionais chinesas de Telecom e seus impactos sobre o Brasil. Dissertação de Mestrado. Brasília: Instituto de Relaçóes Internacionais, 2014, mimeo. 
MALERBA, Franco; NELSON, Richard R. (2012). Economic Development as a Learning Process: Variation Across Sectoral Systems. Massachusetts: Edward Elgar Publishing Ltd.

MDIC, Ministério do Desenvolvimento, Indústria e Comércio Exterior (2012). Principais empresas importadoras - dez. 2012. [http://www.mdic.gov.br/sitio/interna/interna. php?area=5\&menu=3758\&refr=1161] Disponibilidade: 15 dez. 2013.

MOURA, Ruy (2011). PetroChina cria joint venture no Brasil para produzir equipamentos na área de petróleo. Fusões \& Aquisições, julho 25, 2011. [http://fusoesaquisicoes.blogspot.com. br/2011/07/petrochina-cria-joint-venture-no-brasil.html] Disponibilidade: 11 fev. 2014.

MURAKAWA, Fabio (2014). Região já sofre com o fim do superciclo das commodities, Valor Econômico, 24/02/2014. [http://www.valor.com.br/internacional/3440718/regiao-ja-sofre-como-fim-do-superciclo-das-commodities] Disponibilidade: 24 fev. 2014.

NEVES, Maurício (2002). O Setor de Telecomunicaçôes. IN: BNDES, Banco Nacional de Desenvolvimento Econômico e Social. BNDES 50 Anos: Histórias Setoriais. Rio de Janeiro: BNDES, 2002. p. 297-320. [http://www.bndes.gov.br/SiteBNDES/export/sites/default/bndes_pt/ Galerias/Arquivos/conhecimento/livro_setorial/setorial13.pdf] Disponibilidade: 18 dez. 2013.

OLIVEIRA, André L. (2012). O investimento direto das empresas chinesas no Brasil: um estudo exploratório. Rio de Janeiro: UFRJ/COPPE, 2012. [http://objdig.ufrj.br/60/teses/coppe_m/ AndreLuizSoaresDeOliveira.pdf] Disponibilidade: 20 dez. 2013.

OMPI, Organização Mundial de Propriedade Intelectual (2009). Global Economic Slowdown Impacts 2008 International Patent Filings. 27 de janeiro de 2009. [http://www.wipo.int/ pressroom/en/articles/2009/article_0002.html] Disponibilidade: 03 jun. 2013.

OMPI, Organização Mundial de Propriedade Intelectual (2012). International Patent Filings Set New Record in 2011. 05 de março de 2012. [http://www.wipo.int/pressroom/en/articles/2012/ article_0001.html] Disponibilidade: 02 jun. 2013.

OMPI, Organização Mundial de Propriedade Intelectual (2013). Strong Growth in Demand for Intellectual Property Rights in 2012. 19 de março de 2013. [http://www.wipo.int/pressroom/ en/articles/2013/article_0006.html] Disponibilidade: 02 jun. de 2013.

PARAJARA, Fabiana (2003). ZTE a caminho do Ocidente. IstoÉ Dinheiro, edição no 299, 21 mai. 03. [http://www.istoedinheiro.com.br/noticias/11375_ZTE+A+CAMINHO+DO+OCIDENTE] Disponibilidade: 22 dez. 2013.

SHAMBAUGH, David (2013). China Goes Global: the Partial Power. Oxford: Oxford University Press.

STATE GRID BRAZIL HOLDING (2014). Chinese State Grid quer investir US\$ 5 bilhões no Brasil até 2015. [http://www.stategridbr.com/] Disponibilidade: 08 fev. 2014.

SZAPIRO, Marina H. (2012). Capacitações Tecnológicas e Competitivas da Indústria de Equipamentos de Telecomunicaçóes no Brasil. IN: KUBOTA, Luis Claudio MIRANDA, Erasmus Couto Brazil de; MELLO, Luiz Alencar Reis da Silva. Tendências Tecnológicas Mundiais em Telecomunicações e a Influência dos Processos de Normalização e Padronização. Tecnologias da informação e comunicação: competição, políticas e tendências. Brasília: Ipea. [http://www.google. com.br/url? sa=t\&rct=j\&q=\&esrc=s\&source=web\&cd=1\&cad=rja\&ved=0CDIQFjAA\&url= http $\% 3 \mathrm{~A} \% 2 \mathrm{~F} \% 2$ Frepositorio.ipea.gov.br\%2Fbitstream\%2F11058\%2F1157\%2F1\%2FLiv ro_Tecnologias_da_informacao_e_comunica\%25C3\%25A7\%25C3\%25A3o.pdf\&ei=FRqxUurL HarFsATx1YAw\&usg=AFQjCNGxc1WYGQUK_GCeE_dNpEkiKtt5xQ\&bvm=bv.58187178, d.cWc] Disponibilidade: 18 dez. 2013. 
SZAPIRO, Marina H. (2005). Reestruturação do setor de telecomunicações na década de noventa: um estudo comparativo dos impactos sobre o sistema de inovação no Brasil e na Espanha. Tese de Doutorado IE/UFRJ. Rio de Janeiro, 2005.

TAN, Xiaomei (2013). China's overseas investment in the energy/resources sector: Its scale, drivers, challenges and implications. Energy Economics, 36(2013), p. 750-758.

THE HERITAGE FOUNDATION (2014). The China Global Investment Tracker. [http://www.heritage.org/research/projects/china-global-investment-tracker-interactive-map] Disponibilidade: 11 fev. 2014.

UOL (2013) Grupo com Petrobras, Shell, Total e chineses vence 1o leilão do pré-sal. São Paulo, 21/10/2013. [http://economia.uol.com.br/noticias/redacao/2013/10/21/resultado-leilao-presal-libra.htm] Disponibilidade: 11 fev. 2014.

Submitted March 12, 2014 Accepted March 27, 2014

\begin{abstract}
This study aims to understand how Chinese enterprises acted in Brazilian energy and telecommunication sectors in the past ten years and whether they would be leading to an increase in the asymmetries between Brazil and China. It argues that the asymmetries presented in the relations are due in large part to successful Chinese enterprises' strategies.
\end{abstract}

Keywords: China-Brazil relations; Chinese Multinational Corporations; emerging countries; energy sector; telecommunication sector.

\title{
Resumo
}

Este estudo tem como objetivo compreender como empresas chinesas agiram nos setores brasileiros de energia e de telecomunicações nos últimos dez anos e se elas estariam levando a um aumento das assimetrias entre o Brasil e a China. Argumenta-se que as assimetrias apresentadas nas relações resultam em grande medida de estratégias bem-sucedidas usadas por empresas chinesas.

Palavras-chave: relações Brasil-China; Empresas Multinacionais Chinesas; países emergentes; setor de energia; setor de telecomunicações. 